\title{
Ciencia y tecnología para la conservación de matrices de grabado calcográfico
}

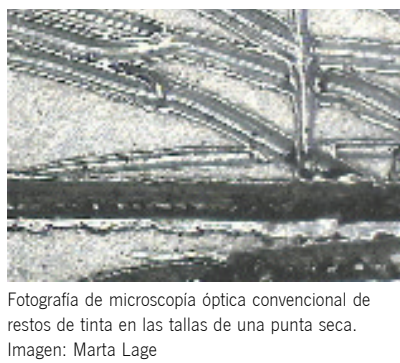

Imagen: Marta Lage
Con la idea de estudiar las matrices de grabado calcográfico, mostrar las actuales líneas de investigación científica en dicho ámbito y crear un foro para su debate y extensión, reforzando al mismo tiempo la necesaria aplicación del conocimiento en ciencia de los materiales a la conservación y recuperación del patrimonio, se reunieron en el Simposio Internacional Ciencia y tecnología para la conservación de matrices de grabado calcográfico (febrero 2005, Madrid) expertos en arte gráfico, especialistas de la conservación y restauración y de la ciencia y tecnología de los materiales, corrosión, técnicas de análisis y protección de soportes con especial y demostrada aplicación en la restauración artística. El encuentro estuvo organizado por la Fundación BBVA en colaboración con la Calcografía Nacional (Real Academia de Bellas Artes de San Fernando).

Dada la trascendencia que suscita la conservación de las láminas calcográficas, en el marco de este foro y por vez primera en la historia, se celebró la reunión de las tres Calcografías europeas, Roma, París y Madrid, que pusieron de manifiesto las necesidades de conservación de las importantes colecciones de matrices que poseen. En el caso de la Calcografía Nacional de Madrid se hizo referencia en concreto a los fondos de Goya, pues se custodian la casi totalidad de matrices grabadas por este artista.

A lo largo de los tres días de Simposio se expusieron primeramente las líneas y técnicas más avanzadas de investigación en el campo de la restauración artística sobre metales; el segundo día se expusieron trabajos científicos aplicados a la conservación de matrices calcográficas, para concluir el último día con las conferencias de restauradores que han trabajado con colecciones de matrices.

De los contenidos de las conferencias y de las mesas redondas establecidas al final de cada una de sesiones, donde debatieron de forma muy activa los expertos y asistentes al Simposio, se pueden extraer de forma breve las siguientes conclusiones:

$>$ Existen herramientas adecuadas para la limpieza y conservación de láminas calcográficas como el plasma frío y el láser. El plasma frío se revela como una técnica muy eficaz dado que se puede actuar sobre la totalidad de la plancha con magníficos resultados mientras que el láser sólo podría actuar sobre pequeñas zonas que se corresponden con la superficie de su spot aplicado. Esto quiere decir que el periodo de tiempo requerido para el tratamiento total de la superficie de la plancha será mayor que con el plasma frío.
$>$ El láser permite la reintegración de material perdido por daño o corrosión de la superficie de las planchas de grabado calcográfico. La inversión del proceso es muy laboriosa para no actuar sobre la zona no dañada.

$>$ Es probable la eliminación de los recubrimientos galvánicos depositados sobre las láminas calcográficas utilizando disoluciones y agentes químicos específicos para sustrato, los cuales a priori, no producen daños en la superficie de las láminas.

> Las 230 matrices de grabado calcográfico de Goya de la Calcografía Nacional presentan recubrimientos galvánicos de diversa tipología aplicados en distintos periodos.

$>$ Más de la mitad de las matrices de Goya presentan algún tipo de deterioro, debido fundamentalmente al paso del tiempo y a las numerosas vicisitudes por las que han pasado a lo largo de la historia.

> La Calcografía de Roma es la institución europea que ha dedicado hasta el momento más recursos para la conservación de su colección de matrices calcográficas, además de ser también la colección más numerosa.

> La Calcografía Nacional de Madrid ha tomado la iniciativa con la organización de este simposio a sentar las bases para la investigación científica aplicada a la conservación del fondo de matrices y hacer especial hincapié en la conservación del legado calcográfico de Goya.

> La Calcografía de París es la que hasta el momento ha dedicado menos atención a la conservación de sus matrices y más a su reproducción, sin embargo en el marco del encuentro su máximo responsable propuso la creación de un equipo multidisciplinar europeo dedicado a la conservación y restauración de las colecciones de matrices calcográficas no sólo de las Calcografías sino de otras instituciones que posean este material en sus fondos.

Todas las contribuciones al Simposio se recogerán en una publicación posterior realizada por la propia Fundación BBVA con la colaboración de la Calcografía Nacional de Madrid.

\section{Marta Lage}

José Manuel Mota

Directores del simposio 